\title{
MSUGT, TMS/TFRS VE BOBİ FRS AÇISINDAN KAVRAMSAL ÇERÇEVE VE FİNANSAL TABLOLARIN SUNULUŞU DEĞERLENDİRILMESI* STANDARTLARININ
}

\author{
Dr. Öğr. Üyesi Özlem Nilüfer KARATAŞ ARACI ${ }^{a}$ \\ Prof. Dr. İsmail BEKÇí
}

Teorik İnceleme

(Theoretical Research)
Muhasebe ve Vergi

Uygulamaları Dergisi

Kasim 2019; 12 (3): 857-884

\section{ÖZ}

Türkiye'de ulusal muhasebe sistemi denildiğinde üç temel düzenlemeden bahsetmek mümkündür. Bunlar; Türkiye Muhasebe Sistemi Uygulamaları Genel Tebliği, Türkiye Muhasebe/Finansal Raporlama Standartları ve 01.01.2018 tarihinden bu yana uygulanmaya başlanan Büyük ve Orta Boy İşletmeler İçin Finansal Raporlama Standardı'dır. Bu düzenlemelerin tamamının amacı doğru, anlaşılabilir, ihtiyaca uygun ve karşılaştııılabilir finansal raporlar sunmaktır. Bu bağlamda ilgili düzenlemelere yol gösteren ve kalbini oluşturan bölümler, bir kavramsal çerçevenin çizildiği ve finansal tabloların sunuluşuna ilişkin ilkelerin yer aldığı bölümlerdir. Dolayısıyla çalışmada bu bölümler Muhasebe Uygulamaları Genel Tebliği, Türkiye Muhasebe/Finansal Raporlama Standartları ve Büyük ve Orta Boy İşletmeler İçin Finansal Raporlama Standardı kapsamında karşılaştırılarak analiz edilmiş farklılık ve benzerlikler ortaya konulmuştur.

Anahtar Sözcükler: Büyük ve Orta Boy İşletmeler için Finansal Raporlama Standard,, Türkiye Finansal Raporlama Standartları, Türkiye Muhasebe Standartları, Muhasebe Sistemi Uygulamaları Genel Tebliği.

JEL Kodları: M41, M42, M48.

APA Stili Kaynak Gösterimi:

Karataş Aracı, Ö. N., Bekçi, İ. (2019). MSUGT, TMS/TFRS Ve BOBİ FRS Açısından Kavramsal Çerçeve Ve Finansal Tabloların Sunuluşu Standartlarının Değerlendirilmesi. Muhasebe ve Vergi Uygulamaları Dergisi. 12 (3), 857-884.

* Makalenin gönderim tarihi: 13.02.2019; Kabul tarihi: 27.03.2019, iThenticate benzerlik oranı \%30 ${ }^{a}$ Mehmet Akif Ersoy Üniversitesi, Konaklama Isşletmeciliği Bölümü, onkaraci@mehmetakif.edu.tr , ORCID: 0000-0001-9761-927X

${ }^{b}$ Süleyman Demirel Üniversitesi, İşletme Bölümü, ismailbekci@sdu.edu.tr. ORCID: 0000-0002-9861-737X

Muhasebe ve Vergi Uygulamaları Dergisi 


\title{
EVALUATION OF CONSEPTUAL FRAMEWORK AND PRESENTATION OF FINANCIAL STATEMENTS STANDARTS IN TERMS OF GCASA, TAS/TFRS AND FRS FOR LMES
}

\begin{abstract}
When called national accounting system in Turkey it is possible to talk about three basic regulations. These are General Communique on Accounting System Application, Turkish Accounting Standards and Financial Reporting Standards and Financial Reporting Standard for Large and Medium Size Enterprises which has been implemented since 01.01.2018. The aim of all these regulations is to provide accurate, comprehensible, tailored and comparable financial reports. In this context, the sections that guide the relevant regulations and form the heart, are the sections in which a conceptual framework is drawn and contain the principles of the financial statements. Therfore in this study, The General Communiqué on Accounting Practices, Turkish Accounting/Financial Reporting Standards and Financial Reporting Standards For Large And Medium-Sized Enterprises have been compared and analysed of differences and similarities have been revealed.
\end{abstract}

Keywords: Financial Reporting Standard for Large andnMedium Size Enterprises, Turkish Accounting Standards, Turkish Financial Reporting Standards, General Communique on Accounting System Application.

JEL Codes: M41, M42, M48.

\section{GíRiş}

1989 yılında yayımlanan 3568 sayılı meslek mensuplarına yönelik düzenlenen kanun ile birlikte 1990'lı y1lların başı muhasebe sisteminin geliştirilmesine yönelik çalışmaların miladı olarak kabul edilebilir. Bu dönemde yürürlüğe giren Vergi Usul Kanunu (VUK), Muhasebe Sistemi Uygulama Genel Tebliğleri (MSUGT) ve Sermaye Piyasası Kurumu (SPK) tebliğleri ile Türkiye muhasebe sisteminin standartlaştırılması yönünde önemli ilerlemeler sağlanmıştır. $\mathrm{Bu}$ ilerlemeler para ve sermaye piyasalarının birleşerek dünya ticaretinde sınırların ortadan kalkmasıyla ticaret hacminin artması gibi nedenlerle ihtiyaç duyulan uluslararası düzenlemelere paralel olarak gerçekleşmiştir. (Altıntaş, 2011, ss. 162-174)

Ulusal anlamda muhasebe uygulamalarının standartlaşmasında dönüm noktası MSUGT iken uluslararası anlamda ise Türkiye Muhasebe Standartları Kurulu (TMSK) tarafindan Uluslararas1 Muhasebe Standartlarının (UMS) benimsenme kararının alınmasıdır. $\mathrm{Bu}$ karar neticesinde TMSK Uluslararası Muhasebe Standartları Vakfı (UMSV) ile bir lisans telif ve anlaşması imzalayarak UMS'yi Türkçe'ye çevirmiştir. Bundan sonra yayımlanan bütün UMS ve Uluslararası Finansal Raporlama Standartları (UFRS), Türkçe' ye çevrilmiş ve UMS'ler Türkiye Muhasebe Standartları (TMS) UFRS'ler ise Türkiye Finansal Raporlama Standartları (TFRS) adlarını almışlardır.

Türkiye'de muhasebe ve finansal raporlama standartlarını, borsada veya teşkilatlanmış bir başka piyasada, ihraç ettikleri sermaye piyasası araçları

Muhasebe ve Vergi Uygulamaları Dergisi 
işlem gören işletmeler, portföy yönetim işletmeleri ve konsolidasyon kapsamında bulunan diğer işletmeler, aracı kurumlar, sigorta ve reasürans şirketleri, bankalar ile bağlı ortaklıkları, emeklilik şirketleri uygularken MSUGT'u bilanço esasına göre defter tutan tüm gerçek ve tüzel kişiler uygulamaktadir.

Bilindiği üzere sosyal bir bilim olan muhasebe, hızla değișen toplumsal ve ticari konjonktüre uyum sağlamak zorundadır. $\mathrm{Bu}$ yüzden bahsi geçen muhasebe kurallarının ve dolayısıyla uygulamalarının zamanın getirdiği koşullara uygun olarak düzenlenmesi ihtiyacı ortaya çıkmaktadır. Türkiye'de bu ihtiyaçlara paralel olarak TMSK'nın yerini Kamu Gözetim Kurulu (KGK) alarak faaliyetlerini sürdürmektedir. Bu kurulun görevlerine örnek olarak TMS ve TFRS ile ilgili düzenlemeler ve revizyonların ihtiyaca uygun olarak yapılması verilebilir. Kurul tarafından son yıllarda yapılan en büyük yeniliklerden bir tanesi; MSUGT' a ek olarak uygulanmak üzere 29/12/2014 tarihli ve 41 sayılı kurul kararıyla "TMS'leri Uygulamayan Şirketlerin Finansal Tablolarının Hazırlanmasında Uygulanacak İlave Hususlar"1 yayımlamasıdır. Bu tebliğin yayımlanmasındaki temel nedenler; MSUGT'un VUK çerçevesinde vergisel kaygılarla hazırlanmış olması, birçok muhasebe kalemiyle ilgili değerleme hükümlerinin olmaması, değerleme hükümlerinin isteğe bağlı olması veya düzenlemede öngörülen değerleme hükümlerinin ne şekilde uygulanması gerektiği ile ilgili herhangi bir açıklama olmamasıdır. Bu durum finansal tabloların ihtiyaca ve gerçeğe uygun, karşılaştırılabilir finansal bilgi sunma amacına hizmet etmemesine sebep olmaktadır.

Ancak bu tebliğinde tam olarak ihtiyacı karşılamadığı görülmüş ve 2015 yılında bu işletmeler için "Yerel Finansal Raporlama Çerçevesi" (YFRÇ) adıyla yayımlanarak taslak olarak kamuoyunun görüşüne sunulmuştur. Ayrıca AB'de UFRS kapsamı dışındaki şirketler için finansal raporlarını, 01/01/2016 tarihinden itibaren 2013/34/EU say1l direktife uygun olarak hazırlama zorunluluğu getirilmiştir. Dolayısıyla $\mathrm{AB}$ katılım müzakereleri çerçevesinde Türk mevzuatının $\mathrm{AB}$ müktesebatı ile uyumlu olması gerekliliği nedeniyle de bu çalışmalar hızlandırılmıştır (Doğan, 2018, s. 117). Gelen görüşler ve ilave çalışmalar sonucunda adı "Büyük ve Orta Boy İşletmeler İçin Finansal Raporlama Standardı” (BOBİ FRS) olarak değiştirilmiştir. BOBİ FRS 29/07/2017 tarihli ve 30138 sayılı Mükerrer Resmi Gazete'de yayımlanarak 01/01/2018 tarihi ve sonrasındaki raporlama dönemlerinde uygulanmak üzere yürürlüğe girmiştir. $\mathrm{Bu}$ standartlar bağımsız denetime tabi olup, TFRS kapsamında olmayan işletmelerin bireysel ve konsolide finansal tablolarının hazırlanmasında bu tarih itibariyle uygulanmaya başlanmıştır.

Çalışmada, nitel araştırma tekniklerinden doküman inceleyerek veri toplama tekniği kullanılmıștır. Bu teknik kapsamında BOBİ FRS, TMS/TFRS ve MSUGT incelenmiş ve konuyla ilgili detaylı bir literatür taraması

Muhasebe ve Vergi Uygulamaları Dergisi 
yapılmıştır. $\mathrm{Bu}$ incelemeler sonucunda düzenlemeler arasındaki farklılık ve benzerlikler ortaya konulmuş özellikle finansal tablo kullanıcıları açısından ne gibi sonuçlar doğurduğu tartışılmıştır.

Çalışmada öncelikle konuyla ilgili yapılan literatür taramasına yer verilmiş, ikinci olarak, farklılık ve benzerliklerin daha iyi anlaşılması için bahsi geçen düzenlemeler ile ilgili genel bilgiler verilmiş, sonrasında tablolar halinde benzerlikler ve farklılıklar sunulmuş sonuç bölümünde ise her üç uygulamayla ilgili genel bir değerlendirme yapılmış ve kavramsal çerçeve ile finansal tabloların sunuluşu çerçevesinde ulaşılan sonuçlar eleştirel bir bakış açısıyla değerlendirilmiştir.

\section{LITERATÜR TARAMASI}

BOBİ FRS ile ilgili ulusal literatür tarandığında aşağıdaki çalışmalara rastlanılmıştır.

Gücenme Gencoğlu (2017), "Temel Konularda BOBİ FRS ve TMS/TFRS Karşılaştırması", Doğan (2017), "Büyük ve Orta Boy İşletmeler için Finansal Raporlama Standardı ile TMS/TFRS Karşılaştırması", Ataman (2017), "TFRS Tam Set İle BOBİ FRS' larına Genel Bakış ve Değerlendirme", Tuncez (2018), "Büyük ve Orta Boy İşletmeler İçin Finansal Raporlama Standardı (Bobi Frs) İle Türkiye Muhasebe Standartları (TMS) Arasındaki Temel Farklılıklar" adlarıyla yayımladıkları makalelerinde; BOBİ FRS'nin, TMS/TFRS" ile temel konularda karşılaştırmasını yapmışlardır. Çalışmalarında genel olarak BOBİ FRS'lerin TMS/TFRS'lerdeki karşılıklarına bakılarak farklıklar ve benzerlikler vurgulanmıştır. Gökçen vd., (2018), “BOBİ FRS ve TFRS'nin Finansal Raporlara Etkileri Açısından Karşılaştırılması" adlı çalışmasında ise BOBİ ve TFRS düzenlemelerini finansal raporlara etkisi özelinde karşılaştırmış ve değerlendirmelerde bulunmuşlardır.

Literatürdeki diğer karşılaştırmalı çalışmalar MSUGT, TMS/ TFRS ve BOBİ FRS arasında yapılmış, benzerlik ve farklılıklar ortaya konulmaya çalışılmıştır. Bu çalışmalara örnek olarak Doğan (2018), "Büyük ve Orta Boy İşletmeler için Finansal Raporlama Standardı ile VUK/MSUGT Karşılaştırması" isimli çalışmasında BOBİ FRS ve MSUGT'u karşılaştırırken, Kıymetli Şen ve Özbirecikli (2018), ise BOBİ FRS'nin Muhasebe Uygulamalarına Getirdiği Değişiklikler: BOBİ FRS, TMS/TFRS ve Mevcut Muhasebe Sistemi Çerçevesinde Bir İnceleme" isimli çalışmalarıyla BOBİ FRS'de yer alan ilkelerin TMS/TFRS ve Muhasebe Sistemi Uygulama Genel Tebliği/Vergi Usul Kanunu (MSUGT/VUK) ile karşılaştırılması suretiyle TMS/TFRS ve MSUGT'ye göre BOBİ FRS'nin Türkiye'de muhasebe uygulamalarına ne gibi değişiklikler getirdiğinin ortaya koymuşlardır. Ataman vd., (2018), "Muhasebe Sistemi Uygulama

Muhasebe ve Vergi Uygulamaları Dergisi 
Genel Tebliği'ne (MSUGT'ye) Göre Hazırlanan Finansal Tabloların Büyük ve Orta Boy İşletmeler İçin Finansal Raporlama Standardı'na (BOBİ FRS'ye) Uyarlanması ve Rasyo Yöntemi İle Analizi" çalışmalarıyla literatürde yer alan makalelerden farklı olarak öncelikle MSUGT'ye göre düzenlenmiş olan bilanço ve gelir tablosu, BOBİ FRS'ye göre uygun finansal durum tablosu ile kar veya zarar tablosuna çevirmiş, düzeltme işlemlerine ilişkin muhasebe kayıtları yapmışlardır. Akabinde çalışmaya konu olan iki düzenleme çerçevesinde ortaya çıkan mali tablolar rasyo yöntemi ile analiz ederek, BOBİ FRS'nin finansal analiz sonuçlarına etkilerini incelemişlerdir.

Öztürk (2017), ise "Tam Maliyet ve Normal Maliyet Yöntemlerinin UFRS (TFRS) ve BOBİ FRS'deki Düzenlemeler Çerçevesinde İncelenmesi” adlı çalışmasında maliyet yöntemleri açısından düzenlemeleri karşılaştırmışlardır.

Karşılaştırma yerine BOBİ FRS'nin genel bir değerlendirmesine yer verdiği çalışmasında Eskin (2017), BOBİ FRS'nin uygulama sürecine ilişkin tespitlerde bulunmuştur.

Gökçen (2017), "Üniversitelerimizde Okutulan Muhasebe Derslerinin İçeriklerinin, TFRS ve BOBİ FRS'lerdeki Gelişmeler Doğrultusunda Yeniden Ele Alınması" adını verdiği çalışmasında durumu ders müfredatları açısından değerlendirmiş ve yapılması gereken değişiklikleri ortaya koymuştur.

Öztürk (2018), "Yerel Finansal Raporlama Çerçevesi ve Büyük ve Orta Boy İşletmeler için Finansal Raporlama Standardı: Bir Literatür İncelemesi (2016 - 2017)" isimli çalışmasında; BOBİ FRS ve ondan önceki taslağı olan YFRÇ ile ilgili hakemli dergilerde yayımlanan makalelere ilişkin bir literatür incelemesi yapmış ve gelecekteki çalışmalar için öneriler sunmuştur.

Tüm bu çalışmalar incelendiğinde değerlendirmelerin genel olarak TMS/ TFRS - BOBİ FRS kapsamında yapıldığı ve birbirine benzer sonuçlar ortaya koyduğu görülmektedir. Tüm mevcut muhasebe sistemimizi içerecek şekilde MSUGT - TMS/TFRS - BOBİ FRS karşılaştırmasını yapan tek bir çalışmaya rastlanılmıştır. Bu çalışma ise değerlendirmelerini temel konular üzerinden genel olarak yapmıştır.

Çalışmanın konusu olan kavramsal çerçeve ve finansal tabloların sunuluşu ile ilgili bölümlere bu çalışmalarda küçük bölümler halinde yer verilmiş ancak detaylı bir inceleme yapılmamıştır. $\mathrm{Bu}$ çalışma ulusal muhasebe standartlarımız diyebileceğimiz tüm bu düzenlemelerin kendi ruhlarını yansıtan onlara yön veren kavramsal çerçeve ve muhasebenin çıktısı olan finansal tabloların sunuluşu standartlarının detaylı olarak incelenmesini amaçlamaktadır. $\mathrm{Bu}$ bölümlerin özümsenmesi düzenlemeler arasındaki 
farklılık ve benzerliklerle ilgili tespit ve değerlendirmelerin daha gerçekçi ve eleştirel bir şekilde yapılması için yol gösterici olacaktır. Ayrıca çalışmaya konu olan TMS/ TFRS Finansal Raporlama İçin Kavramsal Çerçeve yeni yayımlanan ve eskisine göre daha detaylı daha kapsayıcı ve önemli değişiklikler içeren bir düzenlemedir. Çalışmada karşılaştırmalar yeni kavramsal çerçeve üzerinden yapılmıştır.

\section{MUSGT İLE İLGILII GENEL BİLGILLER}

1923 yılında Türkiye Cumhuriyeti Devleti bağımsızlığını ilan etmesiyle özelikle kapitülasyonlarla kaybedilen mali egemenliği geri almıştır. Bu tarihten sonra klasik Osmanlı vergi sistemi tasfiye edilerek Batı Avrupa vergi sistemine uygun bir vergi sistemi geliştirilmeye çalışılmıştır.

1949-50 döneminde önemli bir vergi reformu yapılmış Federal Almanya yasaları örnek alınarak Gelir Vergisi Kanunu, Kurumlar Vergisi Kanunu ve VUK çıkarılmıştır. 1953 yılında Amme Alacaklarının Tahsil Usulü Hakkında Kanun ve 1957 yılında Gider Vergileri Kanunu kabul edilmiştir. 1960 yılında vergi reformu komisyonu kurulmuştur. Bu tarihe kadar bu uygulamalar Alman ekolünün etkisi altında iken, bu tarihten sonra, Türkiye'nin askeri ve ekonomik açıdan ABD ile yakın ilişkiler içine girmesiyle ABD muhasebe sisteminin bel kemiğini oluşturan, Genel Kabul Görmüş Muhasebe İlkeleri doğrultusunda gerçekleştirilmiştir ve muhasebe ile ilgili standardizasyon çalışmaları başlamıştır. (Kayan, 2000, s.84).

440 sayılı "İktisadi Devlet Teşekkülleri ve İștirakleri Hakkında Kanun" 1964 y1lında yürürlüğe girerek Kamu İktisadi Teşebbüsleri'ne (KİT) muhasebe usul ve esaslarının yeknesaklaştırılması yasal zorunluluk olarak öngörülmüş ve bunun için 1971'de Tekdüzen Muhasebe Sistemi Uygulama Komisyonu kurulmuştur. $\mathrm{Bu}$ kurul tarafindan hazırlanan Tekdüzen Muhasebe Sistemi 7/2767 sayılı ve 07/07/1971 tarihli Kararname ile 01/01/1972 tarihinden itibaren belirlenen KIT' lerde uygulamaya konulmuştur. (Öz ve Çevikcan, 2010, s.118).

Tek düzen muhasebe sisteminin oluşturulması için gösterilen çabalar sonucunda, "Muhasebe Usullerinin Islahı ve Yeknesaklaştırılması, Genel Kabul Görmüş Muhasebe Prensipleri ve Muhasebenin Temel Kavramları, Rapor Düzeni, Tekdüzen Hesap Planı ve Açıklamaları, Mali İşler-Muhasebe ve Kontrol Dairelerinin Organizasyonu ile Terimler ve Açıklamalar" adlarıyla 6 adet rapor oluşturulmuş ve yayımlanmıştır. Özellikle 1980'lerden sonra serbest piyasa ekonomisinin benimsenmesi ile uygulamalardaki boşluğu dolduran ve özel sektörde faaliyet gösteren işletmeler için de yol gösterici nitelikte olan bu düzenlemeler, sadece KİT'lerde zorunlu olmasına rağmen daha sonraları diğer işletmelerce de

Muhasebe ve Vergi Uygulamaları Dergisi 
benimsenmiş Türkiye'de muhasebe sisteminin geliştirilmesinde önemli bir paya sahip olmuşlardır (Başpınar, 2005, ss. 46-47).

90'larda muhasebe standartları oluşturma çabaları bir adım öteye götürülmüş Maliye Bakanlığ1 koordinatörlüğünde ve çeşitli kurumlardan temsilcilerin yer aldığı Muhasebe Standartları Komisyonu oluşturulmuş ve muhasebe standartlarının oluşturulması alanında çalışmalar yürütülmüsşür. Komisyon çalışmalarının sonucunda Maliye Bakanlığı'nca VUK kapsamında 26.12.1992 tarihinde 1 sıra no'lu "MSUGT" yayınlanmış ve bu tebliğ ile; "muhasebe temel kavramları, muhasebe politikalarının açıklanması, finansal tablo ilkeleri, finansal tabloların düzenlenmesi ve sunulması ile tekdüzen hesap çerçevesi, hesap planı ve işleyişiı" konularında düzenlemeler yapılmıştır. Sonuncusu 2008 yılında olmak üzere, 1 sıra numaralı Tebliğde ek ve değişiklik yapan toplam 15 tebliğ yayımlanmıştır. MSUGT, Türkiye'de muhasebe sistemini temelden etkilemiştir. Tebliğ ile bilanço esasına göre defter tutan işletmelerin tekdüzen hesap planına geçmesi sağlanmıştır. İlgili tebliğg, aynı zamanda Maliye Bakanlığı için daha etkin bir vergi denetiminin de yolunu açmıştır. Tekdüzen muhasebe sistemi olarak ifade edilen bu değişiklik Türkiye'de muhasebe sistemi anlamında köklü bir değişim yaratmıştır. Muhasebe kayıt düzeni ile finansal raporlamada anlaşılabilirlik ve karşılaştırılabilirlik önem kazanmış, temel finansal tablo olarak belirlenen bilanço ve gelir tablosu için şekil ve içerik anlamında önemli düzenlemeler yapılmıştır. Böylelikle, ülke bazında muhasebenin standartlaştırılması konusunda önemli bir adım atılmıştır (Gözlüklü, 2017, ss. 43-44).

\section{TÜRKIYY MUHASEBE / FINANSAL RAPORLAMA STANDARTLARI ILE ILGILİ GENEL BILGILER}

Birbirinden farklı politik, ekonomik, sosyal ve kültürel koşullar nedeniyle yıllarca ülkeler kendilerine özgü muhasebe uygulamaları kullanmışlardır. Ulusal muhasebe standartları olarak adlandırabilecek bu uygulamalar, bir ülkedeki muhasebe evrensel kavram, kural, yasa, ilke ve yöntemlerine uygun bir şekilde düzenlenen, tekdüzen hesap çerçevesinde oluşan kanun hükümleri, maddeleri ve kurallarından meydana gelen sistemlerdir. İşletmeler ve kurumlar bu oluşturulan sistemlere göre defter tutmakta ve bu sistemlere göre finansal tablolar düzenleyerek hesap vermektedirler (Kocamaz, 2012, s.107). Bu uygulamaların temel amacı ülkedeki işletmelerin ve kurumların muhasebe sistemi içerisinde finansal tablolarında uygulama birliği sağlamaktır. Türkiye deki bu düzenlemeler yukarıda da belirtildiği üzere genel olarak MSUGT etrafında şekillenmiştir.

Fakat uluslararası ticaretin hız ve hacminin artması, çok uluslu olarak faaliyet gösteren işletmelerin sayılarının artması, para ve sermaye piyasalarının küresel entegrasyonu, uluslararası yatırımların dünya 
genelinde hız kazanması bazı gereklilikleri beraberinde getirmiştir. Bu gerekliliklerin en başında ise işletmenin finansal anlamda dişarıya açılan yüzü ve mali dili olan muhasebe sistemlerinin bu değişikliklere ayak uydurması gelmektedir. Bu bağlamda özellikle yatırımların dünya genelinde yapılabiliyor olması ve ticarette sınırların ortadan kalkması mali bilgilerin oluşturulması ve sunulması açısından dünyanın her yerinde aynı anlama gelen dolayısıyla karşılaştırılabilir ve kontrol edilebilir olan ortak bir muhasebe dilinin oluşturulma ihtiyacını ortaya çıkarmıştır. Buna dayanarak 1973 yılında ABD, İngiltere, Kanada, Avustralya, Almanya, Fransa, Japonya, Hollanda, Meksika, ve İrlanda tarafindan Uluslararası Muhasebe Standartları Komitesi - International Accounting Standarts Comitee ( IASC ) kurulmuştur (Başpınar, 2004, s.53). Komitenin amacı, finansal tabloların sunuluşunda ihtiyaç duyulan muhasebe standartlarının oluşturulması, harmonizasyonunun sağlanması ve yapılan çalışmaların kamuoyuyla açık bir şekilde paylaşılmasıdır. Bununla birlikte, komite, farklı ülkelerdeki ulusal muhasebe standartlarını düzenleyen kurumlarla birlikte çalışarak, dünya genelinde muhasebe standartlarını birbirine yakınsamayı amaçlamıştır. 2000 yılına kadar IASC olarak bilinen komite, yeniden yapılanma çalışmaları çerçevesinde, Uluslararası Muhasebe Standartları Kurulu (UMSK) - International Accounting Standards Board (IASB) ismini almıştır. 2000 yılına kadar kurul tarafından yayımlanan standartlar; UMS International Accounting Standards (IAS) adını taşırken, 2000 yılından sonra; UFRS- International Financial Reporting Standards (IFRS ) adını almıştır. Bu yeni başlık adı altında yayımlanan standartlarda ki en göze çarpan farklılık standartların kural bazlı değil ilke bazlı olmasıdır. Uluslararası muhasebe standartlarının ve küçük ve orta boy işletmeler için muhasebe standartlarının geliştirilmesinden ve yayınlanmasından bu kurulun üyeleri sorumludur.

UMSK tarafindan çıkarılan UFRS'ler her geçen gün daha fazla ülkede kabul görmektedir. Bu durum UFRS'leri uluslararasi alanda ortak muhasebe ve finansal raporlama düzenlemeleri olarak kabul edilmektedirler. Birçok ülke ya UFRS'leri kendi dillerine birebir çevirerek kullanmakta ya da bu standartlara paralel düzenlemeler hazırlanmaktadırlar. Örneğin, Mart 2002'de Avrupa Parlamentosu Avrupa Birliği listesindeki tüm işletmelerin en geç 2005 yılında tüm hesaplarını mevcut UMS/UFRS'ler ile uyumlu olarak hazırlamalarını onaylamıştır.

Türkiye de ise UMS'ye uyum süreci 2499 sayılı Sermaye Piyasası Kanununa 18.12.1999 tarih ve 4487 say1lı kanunla eklenen EK-1'inci madde uyarınca; idari ve mali özerkliğe sahip, kamu tüzel kişiliğine haiz bir kurul olan Türkiye Muhasebe Standartları Kurulu (TMSK)'nın kuruluşuyla başlamıştır. TMSK 'nın temel amacı Türkiye ve uluslararası piyasalardaki gelişmeleri yakından takip ederek gelişmiş dünya ülkeleriyle birlikte uluslararası muhasebe standartları ve raporlama standartlarına uyumlu

Muhasebe ve Vergi Uygulamaları Dergisi 
standartlar üretmektir. İlk kurulduğunda TMSK' ya üye veren kuruluşlar; Maliye Bakanlığı, , Bankacılık Düzenleme ve Denetleme Kurulu, Sanayi ve Ticaret Bakanlığı, Hazine Müsteşarlığı, Sermaye Piyasası Kurulu, Yüksek Öğretim Kurulu, Türkiye Odalar ve Borsalar Birliği ve Türkiye Muhasebeciler Odası Birliğgi' dir. Yasada öngörüldüğü şekliyle bu kurulun görevi, denetlenmiş finansal tabloların sunumunda; finansal tabloların gerçek, dengeli, ihtiyaca uygun, güvenilir, anlaşılabilir ve karşılaştırılabilir nitelikte olmaları için ulusal muhasebe ilkelerinin gelişmesi ve benimsenmesini sağlayacak ve kamu yararı için uygulanacak ulusal muhasebe standartlarını tespit etmek ve yayımlamaktır (Akdoğan ve Tenker, 2007, s. 27). Yasada yer alan bu ifadeler standart belirleme ve yayımlama yetkisinin TMSK'ya bırakıldığını göstermektedir.

UMS'nin Türkiye mevzuatına ilk kez girişi ise Sermaye Piyasası Kurulu tebliği ile olmuştur. Türkiye'de Sermaye Piyasası Kanunu'na tabi borsada işlem yapan işletmeler UMS/UFRS ile uyumlu olan SPK Seri:XI, No: 25 Tebliğini 1.1.2005- 09.04.2008 tarihleri arasında uygulamışlardır. Buna göre, hisse senetleri borsada işlem gören işletmeler, portföy yönetim şirketleri ile bu işletmelerin bağlı ortaklığı, yatırım ortaklıkları, hisse senetleri borsada işlem görsün veya görmesin tüm aracı kurumlar, müşterek yönetime tabi ortaklığı ve iştiraki konumunda olan ve konsolidasyon kapsamı dışında tutulmamış olan işletmeler, finansal tablo ve raporlarını tebliğde bahsi geçen UFRS'lere göre düzenlemekle yükümlü olmuşlardır.

TMS ve TFRS ' nin, UFRS' ye uyumlu olması fakat UFRS setindeki standartların tamamının uygulanması ile mümkün olacağı için, TMSK ile Uluslararası Muhasebe Standartları Komitesi Vakfı arasında lisans ve telif sözleşmesi yapılarak TMSK tarafından resmi bir Türkçe çevirinin yapılması öngörülmüsstür. Kamuya Hesap Verme Yükümlülüğü Bulunan İşletmeler (KAYİK), hisseleri veya borçlanma araçları kamuya açık bir piyasada, kredi birliklerinde, hisse senedi arac1/satıcılarında, bankalarda, yatırım fonlarında ve sigorta şirketlerinde işlem gören işletmeler tarafindan Resmi Gazete de yayınlanarak TMS / TFRS'leri uygulama zorunluluğu getirilmiştir (Bekci ve Özdemir, 2006, ss. 146-147).

Daha sonra gelişmelere paralel olarak TMSK'nın yetkileri 2 Kasım 2011 tarihli Kanun Hükmünde Kararname ile "Kamu Gözetimi, Muhasebe ve Denetim Standartları Kurumu” (KGK)' ya devredilmiştir. Şu an KGK tarafından yayımlanmış 26 adet TMS 16 adet TFRS bulunmaktadır. ( http://kgk.gov.tr/DynamicContentDetail/7890/TMS/TFRS-2018-Seti) 


\section{BÜYÜK VE ORTA BOY ISŞLETMELER İÇIN FINANSAL RAPORLAMA STANDARTLARI İLE İLGILİ GENEL BİLGILER}

KGK 2014 yılında TMS/TFRS uygulama kapsamını bağımsız denetim kapsamından ayrıştırarak KAYİK'lerle sınırlandırmıştır. Ancak KAYİK'ler dışında kalan işletmelerinde isteğe bağlı olarak TFRS uygulamalarına izin verilmiştir. TFRS uygulamayan işletmelerin ise geçerli finansal raporlama çerçevesi olarak Maliye Bakanlığı tarafından yayımlanan MSUGT'u uygulamalarına karar verilmiştir. Fakat daha öncede bahsedildiği üzere MSUGT'un VUK'a dayanılarak hazırlanmış olması, bazı kalemlere ilişkin değerleme hükümlerine yer verilmemiş olması, değerleme hükümlerinin ihtiyari bırakılmış olması veya öngörülen değerleme hükümlerinin uygulanma şekline ilişkin esasların açıklanmamış olması nedenleriyle finansal tabloların gerçeğe ve ihtiyaca uygun karşılaştırılabilir finansal bilgi sunma amacını gerçekleştirilemeyeceği değerlendirildiğinden MSUGT' a ek olarak uygulanmak üzere 29/12/2014 tarihli ve 41 sayılı kurul kararıyla "TMS'leri Uygulamayan Şirketlerin Finansal Tablolarının Hazırlanmasında Uygulanacak İlave Hususlar" yayımlanmıștır. Ancak bu tebliğinde tam olarak ihtiyacı karşılamadığı görülmüş ve 2015 yılında bu işletmeler için YFRÇ adıyla bir taslak kamuoyunun görüşüne sunulmuştur. $\mathrm{Bu}$ taslağın amacı; finansal tablo kullanıcılarının ihtiyaçlarına uygun olarak gerçeğe uygun sunum sağlayan kaliteli ve anlaşılabilir finansal tabloların oluşturulmasını sağlamak idi. $\mathrm{Bu}$ doğrultuda akademisyenlerden, piyasa yapıcılardan, muhasebe meslek erbablarından ve konuyla ilgili tüm kesimlerden gelen görüşler ve ilave çalışmalar sonucunda düzenlemenin ismi BOBİ FRS olarak yenilendi ve tebliğ 29/07/2017 tarihli ve 30138 sayılı Mükerrer Resmi Gazete'de yayımlanarak 01/01/2018 tarihi ve sonrasında başlayan raporlama dönemlerinde uygulanmak üzere yürürlüğe girdi.

Tebliğde bu standartları uygulayacak işletmeler detaylı olarak açıklanmıştır. 26/03/2018 tarihli ve 2018/11597 sayılı 'Bağımsız Denetime Tabi Olacak Şirketlerin Belirlenmesine Dair Karar' uyarınca bağımsız denetime tabi olup, 26/8/2014 tarihli ve 29100 sayılı Resmi Gazete'de yayımlanan kurul kararı kapsamında TFRS uygulamayan işletmelerin münferit ve konsolide finansal tablolarının hazırlanmasında uygulanması zorunludur. Aşağıda tablo 1'de bağımsız denetime tabi olacak işletmelerin özellikleri yıllar itibariyle verilmiştir. 2018 yılı itibariyle aktif büyüklüğü 35 Milyon TL, yıllık net satış hasılatı 70 Milyon TL ve çalışan sayısı 175 ve üstü ölçütlerinden en az ikisinin eşik değerlerinin varsa bağlı ortaklıklarıyla beraber art arda iki raporlama döneminde aşan işletmeler izleyen raporlama döneminde bağımsız denetime tabidir. Dolayısıyla KAYİK kapsamında olmayan ancak tablodaki eşik değerleri üst üste iki raporlama dönemi sağlayan işletmeler BOBİ FRS'yi uygulamak zorundadırlar.

Muhasebe ve Vergi Uygulamaları Dergisi 
Tablo-1: Yıllar İtibariyle Bağımsız Denetime Tabi Olma Kriterleri

\begin{tabular}{|c|c|c|c|c|c|}
\hline Kriterler ve Yillar & 2014 & 2015 & 2016 & 2017 & 2018 \\
\hline Aktif Büyüklüğü (Milyon TL) & 75 & 50 & 40 & 40 & 35 \\
\hline Satış Hasılatı (Milyon TL) & 150 & 100 & 80 & 80 & 70 \\
\hline Çalışan Sayısı & $\begin{array}{l}250 \text { ve } \\
\text { üstü }\end{array}$ & $\begin{array}{l}200 \text { ve } \\
\text { üstü }\end{array}$ & $\begin{array}{c}200 \\
\text { ve üstü }\end{array}$ & $\begin{array}{l}200 \text { ve } \\
\text { üstü }\end{array}$ & $\begin{array}{l}175 \text { ve } \\
\text { üstü }\end{array}$ \\
\hline
\end{tabular}

Kaynak: www.kgk.gov.tr

Ayrıca, BOBİ FRS' nin uygulanması açısından, aşağıdaki üç ölçütten en az ikisinin eşik değerlerinin varsa bağlı ortaklıklarıyla beraber art arda iki raporlama döneminde aşan işletmeler izleyen raporlama döneminde büyük işletme olarak değerlendirilirler.

- Aktif toplamı 75 milyon ve üstü Türk Lirası.

- Yıllık net satış hasılatı 150 milyon ve üstü Türk Lirası.

- Ortalama çalışan sayısı 250 ve üstü.

Aktif toplamı ve yıllık net satış hasılatının hesabında dikkate alınan finansal tablolar işletmenin ve bağlı ortaklıklarının BOBİ FRS'ye göre hazırlanmış tablolarıdır. Ayrıca eğer işletmenin BOBİ FRS'ye göre finansal tablo hazırlamayan bağlı ortaklıkları varsa bu bağlı ortaklıkların VUK çerçevesinde hazırlanıp vergi dairelerine ibraz edilen finansal tabloları esas alınır.

Aktif toplam ve yıllık net satış hasılatı hesabı yapılırken konsolide finansal tabloların kullanılması durumunda, BOBİ FRS'nin 'Konsolide Finansal Tablolar Bölümü'nde yer alan eliminasyonlar yapılabilir. Eliminasyonların yapılmaması durumunda tablodaki aktif büyüklüğü ve satış hasılatı tutarına ilişkin asgari tutarlar yüzde 20 artırılarak dikkate alınır.

Büyük işletme tanımını giren bir işletme, tablodaki üç ölçütten en az ikisinin eşik değerlerinin art arda iki raporlama döneminde altında kalması durumunda büyük işletme olarak değerlendirilmez.

BOBİ FRS'yi uygulayan işletmeler iki yıl geçmedikçe isteğe bağlı olarak TFRS'yi uygulayamazlar. Diğer taraftan isteğe bağlı olarak TFRS'yi uygulayan işletmelerin BOBİ FRS'yi uygulayabilmeleri için en az iki yıl TFRS'yi uygulamış olması zorunludur. 
BOBİ FRS 27 bölümden, bireysel ve konsolide finansal tablo örneklerinin yer aldığı ekler ve terimler sözlüğünden oluşur. Genel olarak standartlar incelendiğinde sade ve anlaşılabilir bir dille yazıldığı ve kullanıcılarına sunulduğu görülmektedir. Özellikle terimler sözlüğü standardın rahatlıkla anlaşılabilmesi için yol gösterici nitelikte yazılmıştır.

\section{KAVRAMSAL ÇERÇEVE VE FINANSAL TABLOLARIN SUNULUŞU AÇISINDAN MSUGT, TMS/TFRS ve BOBİ FRS DÜZENLEMELERININ KARŞILAŞTIRILMASI}

MSUGT, TMS/ TFRS ve BOBİ FRS düzenlemelerinin ruhunu ve çerçevesini oluşturan, tüm tarafların standartları anlama ve yorumlamasında yol gösterici olan, finansal raporlamaya ilişkin kavramsal çerçeve ve finansal tabloların sunuluşu ile ilgili düzenlemelerin birbirleriyle farklı ve benzer yönleri bu başlık altında incelenmiş ve ortaya konulmuştur.

Tablo 2' de de görüldüğü üzere her üç düzenleme için yer aldıkları bölümler açısından karşılaştırma yapıldığında kavramsal çerçevenin TMS' de ayrı bir bölüm olarak yer aldığı 1 , finansal tabloların sunuluşu standardının birinci standardı oluşturduğu, BOBİ FRS' de finansal tabloların sunuluşu ile birlikte bir bölümde yer aldığı, MSUGT' da ise ayrı bir bölüm adıyla yer almadığı ancak tebliğin ilk dört bölümünün kavramsal çerçeve ve finansal tabloların sunuluşu standardı olarak değerlendirebileceği görülmektedir.

Tablo-2: Kavramsal Çerçeve ve Finansal Tabloların Sunuluşu Standardının Yer Aldığı Bölümler İtibariyle Karşılaştırma

\begin{tabular}{|c|c|c|}
\hline MSUGT & TMS/TFRS & BOBİ FRS \\
\hline $\begin{array}{l}\text { 1. Bölüm: Muhasebenin } \\
\text { Temel Kavramları, } \\
\text { 2. Bölüm: Muhasebe } \\
\text { Politikalarının } \\
\text { Açıklanması, } \\
\text { 3. Bölüm Mali Tablolar } \\
\text { İlkeleri, } \\
\text { 4.Bölüm: Mali } \\
\text { Tabloların Düzenlenmesi } \\
\text { ve Sunulması }\end{array}$ & $\begin{array}{l}\text { Finansal Raporlamaya } \\
\text { İlişkin Kavramsal Çerçeve } \\
\text { TMS 1 Finansal Tabloların } \\
\text { Sunuluşu }\end{array}$ & $\begin{array}{llr}\text { Bölüm } & \text { 1: } & \text { Kavramsal } \\
\text { Çerçeve } & \text { ve } & \text { Finansal } \\
\text { Tablolar } & & \end{array}$ \\
\hline
\end{tabular}

\footnotetext{
${ }^{1} 2018$ yılı Ekim ayında Finansal Raporlama İçin Kavramsal Çerçeve revize edilerek değiştirilmiştir. $\mathrm{Bu}$ revize kavramsal çerçeveyi; muhasebe politikalarını Kavramsal Çerçeve'ye göre geliştiren finansal tablo hazırlayıcıları için 01/01/2020 tarihi ve sonrasında başlayan yıllık hesap dönemlerinde uygulanacaktır. Çalışmada kavramsal çerçevenin son haline yer verilmiştir.
} 
Genel olarak bu bölümlerde, finansal tabloların sunuluş amacı, temel ve ek finansal tablo setleri, finansal tablolarda kullanılacak bilgilerin niteliksel özellikleri, finansal tabloları oluşturan unsurların tanımı, taşıması gereken özellikler ve ölçümleme esasları hakkında bilgiler sunulmuştur.

Tablodan da anlaşılacağı üzere MUSGT'un kavramsal çerçeve ve finansal tabloların sunuluşu olarak değerlendirilebilecek bölümlerinin genel konsepti 4 başlik altında incelenebilmektedir;

1. Muhasebenin temel kavramları (muhasebenin fonksiyonları yerine getirilirken ve sonucunda raporlama yapılırken hangi temel kavramlara göre yapılacaktır? )

2. Muhasebe politikalarının açıklanması (hangi temel kavramlar finansal tabloların hazırlanmasında belirleyici ve yönlendirici olmalı ve finansal tabloların genel özellikleri neler olmalı?)

3. Finansal tablo ilkeleri (mali tablolar nelerdir? , neden düzenlenirler? , mali tablo düzenlemenin amaçları nelerdir?, mali tablolarda yer alan bilginin niteliksel özellikleri nelerdir? , mali tablolar hangi ilkelere göre düzenlenirler? )

4. Finansal tabloların düzenlenmesi ve sunulması (finansal raporlama kapsamında sunulan mali tabloların biçimsel yapısı, unsurları ve varsayımları nelerdir?)

Hem TMS/TFRS - Finansal Raporlama İçin Kavramsal Çerçeve, hem de BOBİ FRS- Kavramsal Çerçeve ve Finansal Tablolar Standardı'nın genel konsepti ise 3 temel başlık altında incelenebilmektedir. (http://www.bobiturk.com/wp-content/uploads/bobi-frs-muhasebesi-1.pdf Arar, M., 2018, s.12). Bunlar;

1. Finansal raporlamanın amaçları (finansal raporlama hangi nedenlerle yap1lir?)

2. Finansal bilginin niteliksel özellikleri ve finansal tablo unsurları (Finansal raporlamanın amacına bağlı olarak finansal tabloların hangi niteliklere göre hazırlanacak?

3. Ölçme ve değerleme (Finansal raporlamanın varsayımları, değerleme ilkeleri ve kısitları nelerdir?)

$\mathrm{Bu}$ aşamalar kapsamında her 3 düzenleme için karşılaştırmalar yapılmış ve tablolar halinde aşağıda sunulmuştur. Bu başlıklar altındaki açıklamalar bakıldığında, Finansal Raporlama İçin Kavramsal Çerçeve ve BOBİ FRS Kavramsal Çerçeve ve Finansal Tabloların Sunuluşu Standartları finansal tabloların ve raporlamanın amaçlarını açıklamakla başlar. MSUGT ise muhasebe usul ve esaslarına muhasebenin temel kavramlariyla başlamaktadır. Finansal tablo amaçları ise 3. Bölümde finansal tablo ilkeleri başlığının altında finansal tabloların amaçları başlığı ile yer almaktadır.

Muhasebe ve Vergi Uygulamaları Dergisi 
Tablo 3 finansal tablo düzenleme ve raporlamanın amaçlarının, tebliğlerde ne şekilde geçtiğini karşılaştırmaktadır.

Tablo-3: Finansal Raporlamanın Amaçları Açısından Karşılaştırma

\begin{tabular}{|c|c|c|}
\hline MSUGT & TMS/TFRS & BOBİ FRS \\
\hline $\begin{array}{l}\text { 1. Yatırımcılar, kredi } \\
\text { verenler ve diğer ilgililer } \\
\text { için karar almada yararlı } \\
\text { bilgiler sağlamak. } \\
\text { 2. Gelecekteki nakit } \\
\text { akımlarını değerlendirmede } \\
\text { yararlı bilgiler sağlamak. } \\
\text { 3. Varlıklar, kaynaklar ve } \\
\text { bunlardaki değişiklikler ile } \\
\text { işletme faaliyet sonuçları } \\
\text { hakkında bilgi sağlamak. }\end{array}$ & $\begin{array}{lr}\text { Mevcut ve potansiyel } \\
\text { yatırımcılar, borç verenler } \\
\text { ve kredi veren diğer } \\
\text { taraflara, } & \text { raporlayan } \\
\text { işletme } & \text { hakkında; } \\
\text { işletmeye r } & \text { kaynak } \\
\text { sağlamaya yönelik kararlar } \\
\text { verirken yararlı } & \text { olacak } \\
\text { finansal } & \text { bilgiyi } \\
\text { sağlamaktır. } & \end{array}$ & $\begin{array}{l}\text { 1. İşletmenin } \\
\text { durumu, finansal } \\
\text { performansı ve } \\
\text { akışları hakkında ilgili } \\
\text { tarafların } \\
\text { kararlarda faydalı olacak } \\
\text { nitelikte finansal bilgi } \\
\text { sunmaktır. } \\
\text { 2. Yöneticilerin işletmenin } \\
\text { kaynaklarını ne etkinlikte } \\
\text { kullandıklarını gösteren } \\
\text { bilgiler sağlar. }\end{array}$ \\
\hline
\end{tabular}

Her üç düzenlemede de yatırımcılara ve kredi verenlere faydalı finansal bilgi sağlama fonksiyonuna dikkat çekilmiştir. TMS faydalı finansal bilginin kullanımı ile ilgili daha detaylı açıklamalar yaparak kullanılan bilginin hangi kararlar için kullanıldığını da vurgulamıştır. Bu kararlar;

- Özkaynak araçlarının ve borçlanma araçlarının satın alınması, satılmas1 veya elde tutulmas1,

- Kredi sağlanması veya ödenmesi

- Yönetimin işletmenin ekonomik kaynaklarının kullanımını etkileyen faaliyetlerini oylama ya da başka bir şekilde etkileme gibi hakları kullanması, şeklindedir.

MSUGT ve BOBİ FRS ise daha özet açıklamalar yapmıştır.

Faydalı finansal bilginin niteliksel özellikleri, borç verenlere ve kredi veren diğer taraflara, mevcut ve potansiyel yatırımcılara, raporu hazırlayan işletmenin finansal raporunda sunulan bilgilere dayanarak işletme hakkında kararlar alırken yarar sağlayabilecek bilgi türlerinin özelliklerini ifade eder. (Finansal Raporlamaya İlişkin Kavramsal Çerçeve, 2018: 11).

Muhasebe ve Vergi Uygulamaları Dergisi 
MSUGT, TMS/TFRS VE BOBİ FRS AÇISINDAN KAVRAMSAL ÇERÇEVE VE FINANSAL TABLOLARIN SUNULUŞU STANDARTLARININ DEĞERLENDIRILMESI

Tablo-4: Finansal Tablolarda Sunulan Finansal Bilginin Özellikleri Açısından Karşılaştırılma

\begin{tabular}{|c|c|c|c|c|}
\hline MSUGT & \multicolumn{2}{|c|}{ TMS/TFRS } & \multicolumn{2}{|l|}{ BOBİ FRS } \\
\hline $\begin{array}{l}\text { Niteliksel } \\
\text { Özellikler }\end{array}$ & $\begin{array}{l}\text { Temel } \\
\text { Niteliksel } \\
\text { Özellikler }\end{array}$ & $\begin{array}{l}\text { Destekleyici } \\
\text { Niteliksel } \\
\text { Özellikler }\end{array}$ & $\begin{array}{l}\text { Temel } \\
\text { Niteliksel } \\
\text { Özellikler }\end{array}$ & $\begin{array}{l}\text { Destekleyici } \\
\text { Niteliksel } \\
\text { Özellikler }\end{array}$ \\
\hline İhtiyaca Uygunluk & $\begin{array}{l}\text { İhtiyaca } \\
\text { Uygunluk }\end{array}$ & Karşılaştırılabilirlik & $\begin{array}{l}\text { İhtiyaca } \\
\text { Uygunluk }\end{array}$ & $\begin{array}{l}\text { Karşılaştırılabilirl } \\
\text { ik }\end{array}$ \\
\hline Güvenilirlik, & Önemlilik & Anlaşılabilirlik & \multirow{4}{*}{$\begin{array}{l}\text { Gerçeğe } \\
\text { Uygun } \\
\text { Sunum }\end{array}$} & $\begin{array}{l}\text { Zamanında } \\
\text { Sunum }\end{array}$ \\
\hline Anlaşılabilirlik, & \multirow{3}{*}{$\begin{array}{l}\text { Gerçeğe } \\
\text { Uygun } \\
\text { Sunum }\end{array}$} & Doğrulanabilirlik & & \multirow[t]{3}{*}{ Anlaşılabilirlik } \\
\hline Karşılaştırılabilirlik & & Zamanında Sunum & & \\
\hline Zamanında Sunum & & & & \\
\hline
\end{tabular}

Finansal tablolarda sunulacak olan finansal bilginin özelliklerine göre üç düzenleme karşılaştırıldığında TMS/TFRS ve BOBİ FRS' de finansal bilginin özellikleri temel ve destekleyici olarak ikiye ayrılmış, MUSGT da ise böyle bir ayrım yapılmamıştır. İhtiyaca uygunluk, anlaşılabilirlik, karşılaştırılabilirlik ve zamanında sunum özellikleri her üç düzenlemede de vurgulanmıştır. Doğrulanabilirlik ve önemlilik özellikleri sadece TMS'de yer alırken güvenilirlik ise MSUGT' da finansal bilginin taşıması gereken özellikler arasında yer almıştır. Gerçeğe uygun şekilde sunum ifadesi ise TMS ve BOBİ FRS' de temel özellikler arasında yer almış ayrıca bu kavram her iki standartta da birçok bölümde vurgulanmış ve bu özelliğin önemine dikkat çekilmiştir. Her ne kadar önemlilik kavramı MSUGT ve BOBİ FRS' de finansal bilginin özelliklerinde yer almasada MUSGT' da muhasebenin temel kavramlarında, BOBİ FRS' de ise ihtiyaca uygunluk başlığının altında vurgulanmıştır. Yine finansal bilginin niteliksel özellikleri ile ilgili bir başka göze çarpan farklılık ise TMS' de hem temel hem de destekleyici özelliklerin nasıl uygulanacağının detaylı bir şekilde açıklanmasıdır;

Temel niteliksel özelliklerin uygulanması için en verimli ve etkin süreç genelde şu aşamalarda gerçekleşir; Öncelikle, raporlayan işletmenin finansal bilgilerini kullananlara yaralı olabilecek ekonomik olaya ilişkin bilgiler belirlenir, ikinci olarak, ihtiyaca uygun olacak bilgi türü belirlenir, sonrasında ilgili bilginin var olup olmadığı ve ekonomik olayın gerçeğe uygun sunumu gerçekleştirip gerçekleştirmediği belirlenir. Bilgi bu özelliklere sahipse, temel niteliksel özellikleri yerine getirme süreci tamamlanmış olur. Aksi taktirde, süreç bir sonraki ihtiyaca en uygun bilgi türü belirlenerek tekrar edilir (Finansal Raporlamaya İlişkin Kavramsal Çerçeve, 2018: 11). 
Destekleyici niteliksel özelliklerin uygulanmasında ise belirli bir sıra takip edilmez, kendi kendini tekrarlayan bir süreçtir. Bazen, bir niteliksel özelliğin azami seviyeye çıkarılması amacıyla bir diğer destekleyici niteliksel özelliğin azaltılması gerekebilir. Örneğin, yeni bir standardın ileriye yönelik olarak uygulanması sonucunda karşılaştırılabilirlik özelliğinde oluşabilecek geçici bir azalma uzun vadede ihtiyaca uygunluğun veya gerçeğe uygun sunumun geliştirilmesi açısından yararlı olabilir. Gerekli ve uygun açıklamalar, karşılaştırılabilir olmamayı kısmen telafi edebilir (Finansal Raporlamaya İlişkin Kavramsal Çerçeve, 2018: 14).

Diğer tebliğlerde finansal bilginin niteliksel özelliklerinin uygulanmasına dair herhangi bir açıklama yer almamaktadır.

Tablo-5: Finansal Tablolar Seti Açısından Karşılaştırma

\begin{tabular}{|c|c|c|c|c|}
\hline \multicolumn{2}{|l|}{ MSUGT } & \multicolumn{2}{|l|}{ TMS/TFRS } & \multirow{2}{*}{$\begin{array}{l}\text { BOBİ FRS } \\
\text { Zorunlu } \\
\text { Finansal } \\
\text { Tablolar }\end{array}$} \\
\hline $\begin{array}{l}\text { Temel } \\
\text { Mali } \\
\text { Tablolar }\end{array}$ & $\begin{array}{l}\text { Ek Mali } \\
\text { Tablolar }\end{array}$ & $\begin{array}{l}\text { Genel Amaçlı } \\
\text { (Zorunlu) } \\
\text { Finansal } \\
\text { Tablolar }\end{array}$ & $\begin{array}{l}\text { Özel } \quad \text { Amaçlı } \\
\text { Finansal Tablolar }\end{array}$ & \\
\hline Bilanço & $\begin{array}{l}\text { Satışların } \\
\text { Maliyeti } \\
\text { Tablosu }\end{array}$ & $\begin{array}{l}\text { Finansal Durum } \\
\text { Tablosu, }\end{array}$ & \multirow{6}{*}{ 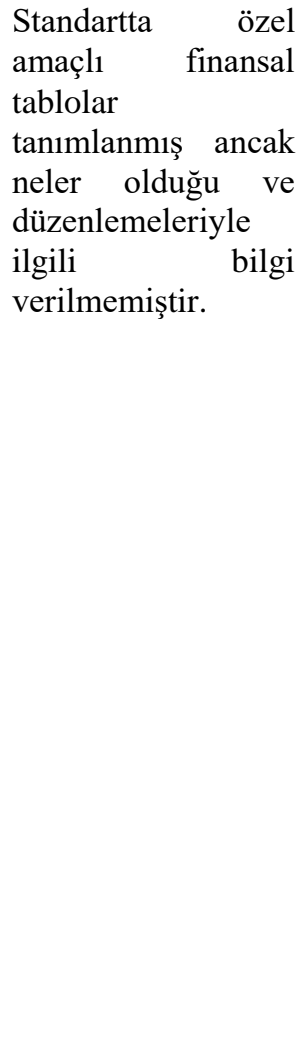 } & $\begin{array}{l}\text { Finansal Durum } \\
\text { Tablosu, }\end{array}$ \\
\hline $\begin{array}{l}\text { Gelir } \\
\text { Tablosu }\end{array}$ & $\begin{array}{l}\text { Fon Akım } \\
\text { Tabloları }\end{array}$ & $\begin{array}{ll}\text { Kâr Veya } & \text { Zarar } \\
\text { Ve } & \text { Diğer } \\
\text { Kapsamlı } & \text { Gelir } \\
\text { Tablosu, } & \end{array}$ & & $\begin{array}{l}\text { Kâr veya Zarar } \\
\text { Tablosu, }\end{array}$ \\
\hline \multirow[t]{4}{*}{ Dipnotlar } & $\begin{array}{l}\text { Nakit } \\
\text { Akım } \\
\text { Tablosu }\end{array}$ & $\begin{array}{l}\text { Özkaynak } \\
\text { Değişim } \\
\text { Tablosu, }\end{array}$ & & $\begin{array}{l}\text { Özkaynak } \\
\text { Değişim } \\
\text { Tablosu, }\end{array}$ \\
\hline & $\begin{array}{l}\text { Kâr } \\
\text { Dağıtım } \\
\text { Tablosu }\end{array}$ & $\begin{array}{ll}\text { Nakit } & \text { Akış } \\
\text { Tablosu, } & \end{array}$ & & $\begin{array}{ll}\text { Nakit } & \text { Akış } \\
\text { Tablosu, } & \end{array}$ \\
\hline & $\begin{array}{l}\text { Öz } \\
\text { Kaynaklar } \\
\text { Değişim } \\
\text { Tablosu }\end{array}$ & $\begin{array}{l}\text { Önemli } \\
\text { Muhasebe } \\
\text { Politikalarını Ve } \\
\text { Diğer Açıklayıcı } \\
\text { Bilgileri İçeren } \\
\text { Dipnotlar, }\end{array}$ & & $\begin{array}{l}\text { Önemli } \\
\text { Muhasebe } \\
\text { Politikalarını Ve } \\
\text { Diğer Açıklayıcı } \\
\text { Bilgileri İçeren } \\
\text { Dipnotlar, }\end{array}$ \\
\hline & & $\begin{array}{lr}\text { Bir Önceki } \\
\text { Döneme Ait } \\
\text { Karşılaştırmalı } \\
\text { Bilgiler }\end{array}$ & & $\begin{array}{lr}\text { Bir Önceki } \\
\text { Döneme Ait } \\
\text { Karşılaştırmalı } \\
\text { Bilgiler }\end{array}$ \\
\hline
\end{tabular}

Muhasebe ve Vergi Uygulamaları Dergisi 
Her üç uygulama sunulması zorunlu ve isteğe bağlı olan finansal tablolar açısından değerlendirildiğinde TMS 1 Finansal Tabloların Sunuluşu Standardı'ında ve BOBİ FRS'de zorunlu finansal tabloların genel amaçlı finansal tablolar adıyla standartlarda yer aldığ 1 ve her iki standartta da aynı olduğu görülmektedir. Ek finansal tablolar ise özel amaçlı finansal tablolar olarak değerlendirilmiş ancak bu tablolarla ilgili bir düzenleme yapılmamıştır. Üç düzenleme arasındaki farklardan bir diğeri ise; TMS 1'de Kâr veya Zarar ve Diğer Kapsamlı Gelir Tablosu'nun adı BOBİ FRS'de Kar veya Zarar Tablosu olarak MSUGT'da ise sadece gelir tablosu adiyla yer almasıdır. Yine Finansal Durum Tablosu BOBİ FRS'de aynı adla yer alırken MSUGT'da Bilanço adıyla yer almaktadır.

Hem BOBİ FRS'DE hem de TMS 1'de, finansal tabloların işletmenin finansal durumunu, finansal performansını ve nakit akışlarını gerçeğe uygun bir şekilde sunması, açık ve anlaşılabilir bir şekilde hazırlaması gerekliliği üzerinde durulmuştur.

Ayrıca Finansal Raporlama İçin Kavramsal Çerçeve'de finansal tablolar, ile ilgili bölümde raporlayan işletme tanımının da detaylı olarak üzerinde durulmuştur. Buna göre raporlayan işletme; finansal tablolar hazırlamakla yükümlü olan ya da finansal tablolar hazırlamayı seçen bir işletmedir. Bir raporlayan işletme, tek bir işletme olabileceği gibi işletmenin bir kısmından veya birden fazla işletmeden oluşabilir. Bir raporlayan işletmenin tüzel kişi olması şart değildir. Bazen bir işletme (ana ortaklık) başka bir işletme (bağlı ortaklık) üzerinde kontrole sahiptir. Bir raporlayan işletme hem ana ortaklıktan, hem de onun bağlı ortaklıklarından oluşuyorsa, raporlayan işletmenin finansal tabloları 'konsolide finansal tablolar' olarak ifade edilir. Raporlayan işletme sadece ana ortaklık ise raporlayan işletmenin finansal tabloları 'konsolide olmayan finansal tablolar' olarak ifade edilir.

Görüldüğü üzere TMS'de kavramsal çerçeve de finansal tablolarda konsolide - konsolide olmayan ayrımı yaparak detaylı tanımlamalarına yer verilmiştir. Diğer düzenlemelerde kavramsal çerçeve kapsamında raporlayan işletme, konsolide ve konsolide olmayan finansal tablo tanımlarına rastlamak mümkün değildir. BOBİ FRS'de 'Bölüm 22 Konsolide Finansal Tablolar' konsolide finansal tablo tanımına rastlamak mümkündür. 
Tablo-6: Finansal Raporlama İlkeleri Açısından Karşılaştırma

\begin{tabular}{|c|c|c|}
\hline $\begin{array}{l}\text { MSUGT } \\
\text { Kavramlar) }\end{array}$ & $\begin{array}{l}\text { TMS/TFRS } \\
\text { (Raporlamanın } \quad \text { Genel } \\
\text { Özelliği) }\end{array}$ & $\begin{array}{l}\text { BOBİ FRS (Genel } \\
\text { Finansal Raporlama } \\
\text { İlkeleri ) }\end{array}$ \\
\hline $\begin{array}{ll}\text { - } & \text { Sosyal } \\
& \text { Sorumluluk } \\
\text { - } & \text { Kişilik } \\
\text { - } & \text { İşletmenin } \\
& \text { Sürekliliği } \\
\text { - } & \text { Dönemsellik } \\
& \text { Kavramı } \\
\text { - } & \text { Parayla Ölçülme } \\
\text { - } & \text { Maliyet Esası } \\
\text { - } & \text { Tarafsızlık } \\
& \text { Belgelendirme } \\
\text { - } & \text { Tutarlılık } \\
\text { - } & \text { Tam Açıklama } \\
\text { - } & \text { İhtiyatlılık } \\
\text { - } & \text { Önemlilik } \\
& \text { Kavramı } \\
\text { - } & \text { Özün Önceliği }\end{array}$ & $\begin{array}{ll}\text { - } & \text { İşletmenin } \\
& \text { Sürekliliği, } \\
\text { - } & \text { Tahakkuk Esası, } \\
\text { - } & \text { Önemlilik ve } \\
& \text { Birleştirme, } \\
\text { - } & \text { Netleştirme, } \\
\text { - } & \text { Raporlama Sıklığı, } \\
\text { - } \quad \text { Karşılaştırmalı } & \text { Bilgi, } \\
\text { - Sunuluşun } \\
\text { Tutarlılığ1 }\end{array}$ & $\begin{array}{ll}- & \begin{array}{l}\text { İşletmenin } \\
\text { sürekliliği }\end{array} \\
- & \text { Tahakkuk esası } \\
- & \text { Önemlilik } \\
- & \text { Mahsup yasağı } \\
- & \text { İhtiyatlılık } \\
- & \text { Raporlamanın } \\
& \text { sıklığ1 } \\
- & \text { Karşılaştırmalı } \\
\text { bilgi } \\
\text { - }\end{array}$ \\
\hline
\end{tabular}

TMS/TFRS “raporlamanın genel özellikleri” ve BOBİ FRS' de "genel finansal raporlama ilkeleri" MSUGT'da ise muhasebenin temel kavramları adıyla yer alan ilkelere baktığımızda ortak vurgu yapılan kavramların; işletmenin sürekliliği, önemlilik ve tutarlılık olduğu göze çarpmaktadır. BOBİ FRS ve TMS'nin ilkeler açısından ihtiyatlılık dışında örtüştüğü görülmektedir, ancak her ne kadar ihtiyatlılık kavramına TMS' de başlık olarak yer verilmese de hem finansal raporlama için kavramsal çerçevede hem de TMS 1 metinlerini genelinden bu kavramın birçok yerde vurgulandığı göze çarpmaktadır. Her üç uygulamada da ihtiyatlılık ilkesine riayet edilerek özellikle muallak olan durumlarda tahmin yapılması gerektiğinde varlık ve gelirlerin olduğundan daha fazla, yükümlülük ve borçların ise olduğundan daha az belirlenmemesi için gerekli özenin gösterilmesi gerektiği vurgulanmıştır (Gençoğlu, 2017:4). MUSGT’a bakıldığında ise finansal raporlama ilkelerine muhasebenin temel kavramları başlığı altında daha detaylı olarak ele alındığı diğer iki uygulamaya göre sosyal sorumluluk, kişilik, dönemsellik, parayla ölçülme, maliyet esası, tarafsızlık ve belgelendirme, tam açıklama ve özün önceliği kavramlarının da tek tek açıklandığı ve uygulanmasının zorunluğu olduğu belirtilmiştir. Her üç uygulamada da finansal tablolar nakit akım tablosu hariç tahakkuk 
esasına göre düzenlenmektedir. Yukarıdaki Tablo 5'te yer almayan muhasebenin diğer temel kavramları, genel raporlama ilkeleri başlığ 1 altında ayrı ayrı sıralanmamakla birlikte TMS/TFRS ve BOBİ FRS'de zımni olarak kabul edildiği görülmektedir. Örneğin TMS'de finansal raporlama için kavramsal çerçeve de gerçeğe uygun sunum başlı̆̆ 1 altında ihtiyatlılık vurgusu, karşılaştırılabilirlik başlığ 1 altında tutarlılık vurgusu net bir şekilde yer almıştır.

Tablo-7: Finansal Tablolarda Yer alması Gereken Bilgiler Açısından Karşılaştırma

\begin{tabular}{|c|c|c|}
\hline MSUGT & TMS/TFRS & BOBİ FRS \\
\hline $\begin{array}{l}\text { - Bu düzenlemede } \\
\text { finansal tablolarda } \\
\text { yer alması gereken } \\
\text { bilgiler başlığı } \\
\text { bulunmamasına } \\
\text { rağmen, diğer iki } \\
\text { düzenlemede yer } \\
\text { alan bilgilerin } \\
\text { tamamı muhasebe } \\
\text { temel kavramlarının } \\
\text { içeriği } \\
\text { incelendiğinde } \\
\text { birebir kendisine } \\
\text { yer bulmuştur. }\end{array}$ & 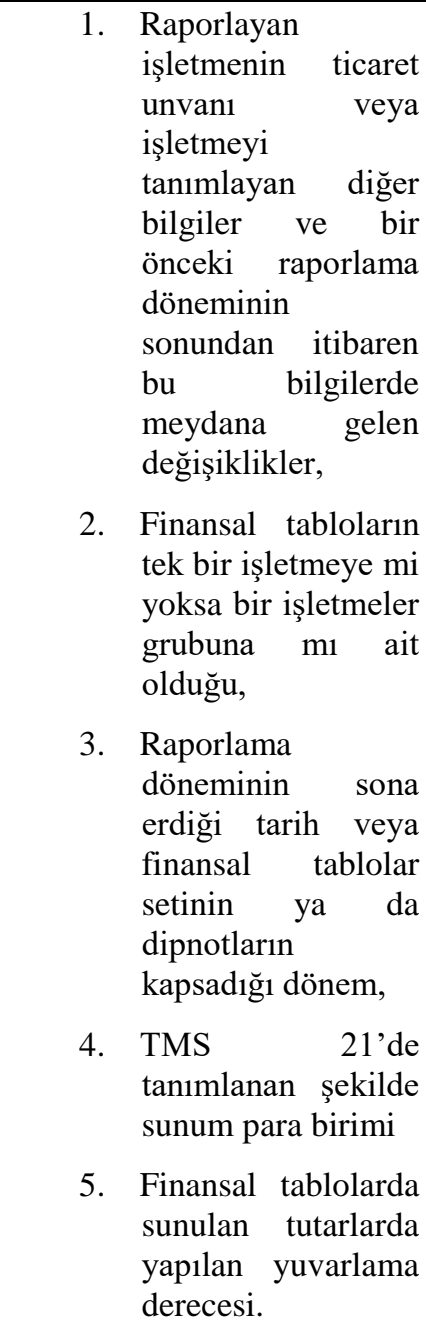 & $\begin{array}{l}\text { 1. Raporlayan } \\
\text { işletmenin ticaret } \\
\text { unvanı ve önceki } \\
\text { raporlama } \\
\text { döneminden bu } \\
\text { yana unvanda } \\
\text { meydana gelen } \\
\text { değişiklikler, } \\
\text { 2. Finansal tabloların } \\
\text { tek bir işletmenin } \\
\text { finansal tabloları } \\
\text { mı yoksa konsolide } \\
\text { finansal tablolar mı } \\
\text { olduğu, } \\
\text { Raporlama } \\
\text { döneminin sona } \\
\text { erdiği tarih ve } \\
\text { finansal tabloların } \\
\text { kapsadığı dönem, } \\
\text { Finansal tabloların } \\
\text { sunulduğu para } \\
\text { birimi r } \\
\text { Finansal tablolarda } \\
\text { yer alan tutarlarda } \\
\text { yuvarlama yapılmış } \\
\text { ise, yuvarlamanın } \\
\text { derecesi. }\end{array}$ \\
\hline
\end{tabular}

Tablo 7'da görüleceği üzere finansal tablolarda yer alması gereken bilgiler açısından aynı başlık altında olmasa da her üç düzenleme birbiriyle genel olarak örtüşmektedir.

Muhasebe ve Vergi Uygulamaları Dergisi 
Finansal tabloların unsurları düzenlemeler itibariyle Tablo 8, Tablo 9 ve Tablo 10'da yer almaktadır.

Tablo-8: MSUGT Finansal Tabloların Unsurları

\begin{tabular}{|c|c|c|}
\hline $\begin{array}{l}\text { Ait Olduğu Finansal } \\
\text { Tablo }\end{array}$ & Unsurlar & Açıklama \\
\hline Bilanço & Varlıklar & $\begin{array}{l}\text { Varlıklar, dönen ve duran } \\
\text { olarak adlandırılan iki grupta } \\
\text { yer almaktadır. Dönen } \\
\text { varlıklar grubunda, bir yıl } \\
\text { veya işletmenin normal } \\
\text { faaliyet dönemi içinde paraya } \\
\text { çevrileceği veya kullanılacağı } \\
\text { tahmin edilen varlıklar yer } \\
\text { alırken, duran varlıklarda ise, } \\
\text { normal şartlar altında bir sene } \\
\text { içerisinde elden çıkarılması } \\
\text { düşünülmeyen veya faydaları } \\
\text { bir senede tükenmeyecek } \\
\text { olan varlıklar yer alır. }\end{array}$ \\
\hline Bilanço & Kaynaklar & $\begin{array}{l}\text { Kaynaklar, kısa ve uzun } \\
\text { vadeli yabancı kaynaklarla } \\
\text { özkaynaklardan oluşur. Kısa } \\
\text { vadeli yabancı kaynaklar bir } \\
\text { sene içinde ödenmesi } \\
\text { gereken; uzun vadeli yabancı } \\
\text { kaynaklar ise bir seneden } \\
\text { sonra ödenecek olan } \\
\text { borçlardan oluşur. } \\
\text { Özkaynaklar ise işletme sahip } \\
\text { veya ortakları tarafindan } \\
\text { işletme kişiliğine tahsis } \\
\text { edilmiş kaynaklarıdır. }\end{array}$ \\
\hline Gelir Tablosu & Gelir & $\begin{array}{l}\text { Tanımı yapılmamış, } \\
\text { tablodaki tüm kalemler tek } \\
\text { tek ve ayrıntılı olarak mali } \\
\text { tabloların düzenlenmesi ve } \\
\text { sunulması bölümünde } \\
\text { ayrıntılı olarak açıklanmıştır. }\end{array}$ \\
\hline Gelir Tablosu & Gider & $\begin{array}{l}\text { Tanımı yapılmamış, } \\
\text { tablodaki tüm kalemler tek } \\
\text { tek ve ayrıntılı olarak mali } \\
\text { tabloların düzenlenmesi ve } \\
\text { sunulması bölümünde } \\
\text { ayrıntılı olarak açıklanmıştır. }\end{array}$ \\
\hline
\end{tabular}


Tablo-9: TMS/TFRS Finansal Tabloların Unsurları

\begin{tabular}{|c|c|c|c|}
\hline Sinıflandırma & $\begin{array}{l}\text { Finansal } \\
\text { Tablolar }\end{array}$ & Unsurlar & Açıklama \\
\hline Ekonomik Kaynak & $\begin{array}{ll}\text { Finansal } & \text { Durum } \\
\text { Tablosu } & \end{array}$ & Varlıklar & \begin{tabular}{lcr} 
Geçmişteki & \multicolumn{2}{c}{ olayların bir } \\
sonucu olarak işletme \\
tarafından & kontrol edilen \\
mevcut ekonomik fayda & furetme potansiyeline sahip bir \\
urretme & hak olan ekonomik kaynaklar
\end{tabular} \\
\hline \multirow[t]{2}{*}{ Talep Hakkı } & \multirow[t]{2}{*}{$\begin{array}{ll}\text { Finansal Durum } \\
\text { Tablosu }\end{array}$} & Yükümlülükler & $\begin{array}{l}\text { İ̧sletmenin geçmişteki } \\
\text { olayların bir sonucu olarak bir } \\
\text { ekonomik kaynağı devretme } \\
\text { konusundaki mükellefiyeti. }\end{array}$ \\
\hline & & Özkaynaklar & $\begin{array}{l}\text { İşletmenin } \\
\text { yükümlülükleri düm } \\
\text { sonräräldükten } \\
\text { hak. }\end{array}$ \\
\hline \multirow[t]{2}{*}{$\begin{array}{l}\text { Finansal } \\
\text { performansı } \\
\text { yansıtan, } \\
\text { ekonomik } \\
\text { kaynaklarda ve } \\
\text { talep haklarındaki } \\
\text { değişiklikler }\end{array}$} & \multirow[t]{2}{*}{$\begin{array}{ll}\text { Kâr Veya } & \text { Zarar } \\
\text { Ve } & \text { Diğer } \\
\text { Kapsamlı } & \text { Gelir } \\
\text { Tablosu } & \end{array}$} & Gelir & \begin{tabular}{l}
\multicolumn{2}{l}{ Özkaynak üzerindeki talep } \\
hakkı sahiplerinin yaptığı \\
katkılar hariç, özkaynakta \\
artışlara $\quad$ yol \\
yükümlülüklerdeki açan \\
veya varlıklardaki artışlar
\end{tabular} \\
\hline & & Gider & $\begin{array}{l}\text { Özkaynak üzerindeki talep } \\
\text { hakkı sahiplerine yapılan } \\
\text { dağıtımlar } \\
\text { özkaynaklarda azalışlara yol } \\
\text { açan yüriç, } \\
\begin{array}{l}\text { artışlar veya varlı̈lklerdeki } \\
\text { azalışlar }\end{array}\end{array}$ \\
\hline \multirow{2}{*}{$\begin{array}{l}\text { Ekonomik } \\
\text { kaynaklarda ve } \\
\text { talep haklarındaki } \\
\text { diğer değişiklikler }\end{array}$} & - & - & $\begin{array}{l}\text { Özkaynak üzerindeki talep } \\
\text { hakkı sahiplerinin katkıları ve } \\
\text { onlara yapılan dağıtımlar }\end{array}$ \\
\hline & - & - & $\begin{array}{l}\text { Özkaynakta artış veya azalışa } \\
\text { yol açmayan varlıklardaki } \\
\text { veya yükümlülüklerdeki } \\
\text { değişiklikler. }\end{array}$ \\
\hline
\end{tabular}

Kaynak: Finansal Raporlamaya İlişkin Kavramsal Çerçeve, 2018, s.20 
Özlem Nilüfer KARATAŞ ARACI - İsmail BEKÇI

Tablo-10: BOBİ FRS Finansal Tabloların Unsurları

\begin{tabular}{|c|c|c|}
\hline $\begin{array}{l}\text { Finansal } \\
\text { Tablolar }\end{array}$ & Unsurlar & Açıklama \\
\hline $\begin{array}{l}\text { Finansal } \\
\text { Durum } \\
\text { Tablosu }\end{array}$ & Varliklar & $\begin{array}{l}\text { Geçmişte meydana gelen olaylar sonucunda ortaya } \\
\text { çıan işletmenin kontrolünde olup gelecekte } \\
\text { işletmeye ekonomik fayda sağlaması beklenen } \\
\text { değerlerdir. }\end{array}$ \\
\hline \multirow[t]{2}{*}{$\begin{array}{l}\text { Finansal } \\
\text { Durum } \\
\text { Tablosu }\end{array}$} & Yükümlülükler & $\begin{array}{l}\text { Yükümlülükler, geçmişte meydana gelen olaylardan } \\
\text { kaynaklanan ve yerine getirilmesi durumunda } \\
\text { ekonomik fayda sağlayan değerlerin işletmeden } \\
\text { çıkışına neden olacak mevcut mükellefiyetlerdir. }\end{array}$ \\
\hline & Özkaynaklar & $\begin{array}{l}\text { İşletme varlıklarından işletmeye ait tüm } \\
\text { yükümlülüklerin indirilmesi sonucunda geriye kalan } \\
\text { paylardır. }\end{array}$ \\
\hline \multirow[t]{2}{*}{$\begin{array}{l}\text { Kâr Veya } \\
\text { Zarar } \\
\text { Tablosu }\end{array}$} & Gelir & $\begin{array}{l}\text { Gelirler, varlık girişi veya varlıkların değerinde artış } \\
\text { ya da yükümlülüklerde azalma ş̧eklinde } \\
\text { özkaynaklarda ortaklardan alınanlar meydana gelen } \\
\text { artıştır. }\end{array}$ \\
\hline & Gider & $\begin{array}{l}\text { Giderler, varlık çıkışı veya varlıkların değerinde } \\
\text { azalış ya da yükümlülüklerde artış şeklinde } \\
\text { özkaynaklarda ortaklara dağıtılanlar hariç raporlama } \\
\text { dönemi boyunca meydana gelen azalıştır. }\end{array}$ \\
\hline
\end{tabular}

Finansal durum tablosu (bilanço), kar zarar tablosu, nakit akım tablosu ve özkaynak değişim tablosunun asgari unsurları her üç tebliğ de de belirtilmiştir. Bunun dışında kalan ek finansal tablolar ya da özel amaçlı finansal tablolar diye adlandırılan fon akım, kar dağıtım, satışların maliyeti gibi tablolar ile ilgili TMS/TFRS ve BOBİ FRS de özel olarak bilgi verilmezken MSUGT bu tablolarında asgari unsurları ve şekil şartlarını belirtmiştir. TMS/TFRS' de genel amaçlı finansal tabloların asgari unsurları açıklanmasına rağmen belirli bir tablo şeklinden bahsedilmektedir. Ancak KGK, uygulayıcılara kolaylık olması ve uygulamada birlik sağlanması açısından genel hatlarıyla örnek hem bireysel hem de konsolide finansal tablolar yayınlamıştır. BOBİ FRS ve MSUGT' da ise tebliğler de ekler bölümünde tüm finansal tabloların şekil itibariyle nasıl düzenlenmesi gerektiği yayımlanmıştır. Bu bağlamda BOBİ FRS' de yer alan finansal durum tablosu, kar zarar tablosu, özkaynak değişim tablosu ve nakit akış tablosu formatları genel olarak TMS/TFRS'ler ile uyumludur. Ancak tablolar itibariyle bazı önemli farklılıkları da görmek mümkündür. İki standart setinin ise MSUGT ile karşılaştırıldığında biçimsel ve niteliksel açıdan büyük farklılıklar bulunduğu görülmektedir.

$\mathrm{Bu}$ bağlamda ilk olarak finansal durum tablosu'nun (bilanço) unsurları açısından üç uygulamayı karşılaştırdığımızda; her üç düzenlemede de,

Muhasebe ve Vergi Uygulamaları Dergisi 
varlıklar, yükümlülükler ve özkaynakların tablonun asgari unsurları olduğu görülmektedir. Varlıklar ve yükümlülüklerin tanımı ve finansal durum tablosunda yer alabilmesi için gerekli şartlar TMS ve BOBİ FRS' de aynıdır. Ancak TMS tanımlamaları yaparken ekonomik kaynak ve talep hakkı çerçevesinde yapmıştır. MSUGT' da ise varlık ve kaynak tanımlamaları yapılmamış gerekli şartlar gibi genel bir ifade yer almamış ancak bu kapsama giren tüm kalemler Tek Düzen Hesap Planı çerçevesinde bilançonun biçimsel yapısında tek tek tanımlanmıştır. Öte yandan üç tebliğde de varlıklar ve yükümlülükler ile ilgili kısa ve uzun vade ayrımı yapılmakta bu ayrımda faaliyet döngüsü veya 12 ay baz alınmaktadır. $\mathrm{Bu}$ bağlamda varlıklar için dönen ve duran varlık, yükümlülükler için kısa ve uzun vadeli ayrımı yapılmıştır.

Finansal durum tablosu ile ilgili bir başka göze çarpan husus, kıdem tazminatı karşılıkları noktasındadır. BOBİ FRS'de TMS'de yer alan 'Çalışanlara Sağlanan Faydalar' ve 'Emeklilik Fayda Planlarında Muhasebeleştirme ve Raporlama' bölümleri yer almadığından MSUGT' da ki gibi "kıdem tazminatı karşılıkları" kalemi sadece kısa ve uzun vadeli yabancı kaynaklar içerisinde yer almaktadır (Gücenme Gencoğlu, 2017, s.5).

Bir diğer farklılık ise MSUGT'da olmayan Türk muhasebe sistemine UFRS'lerle birlikte girmiş bir kavram olan ertelenmiş vergi varlığı ve ertelenmiş vergi yükümlüğü kalemlerinin raporlanması hususundadır. $\mathrm{Bu}$ husus TMS/TFRS ve BOBİ FRS kullanarak raporlama yapan işletmelerde finansal durum tablosunda duran varlıklar içerisinde 'ertelenmiş vergi varlı̆̆ı', uzun vadeli yükümlülükler içerisinde ise 'ertelenmiş vergi yükümlülüğ̈̈' olarak yer almaktadır. Ancak bu durum BOBİ FRS kullanarak raporlama yapan büyük işletmeler için geçelidir. Orta boy işletmelerde böyle bir raporlama söz konusu değildir.

Son olarak göze çarpan, sadece finansal durum tablosunu değil kar zarar tablosunda da raporlama açısından farklılık yaratabilecek konu BOBİ FRS ve MSUGT'da, TMS/TFRS'lerde yer alan satış amaçlı duran varlıklar ve durdurulan faaliyetler kavramlarının yer almamasıdır. Bu bölümler finansal durum tablosunda MSUGT ve BOBİ FRS'de olmadığı için kar veya zarar tablosunda da sürdürülen ve durulan faaliyet sonuçlarının ayrı ayrı gösterilip raporlanması gibi bir durum söz konusu değildir.

Karşılaştırma kâr veya zarar tablosunun unsurları açısından yapıldığında ise şu sonuçlara ulaşmak mümkündür:

Her üç düzenlemede de tablonun asgari unsurlarının gelir ve giderlerden oluştuğunu görmek mümkündür. 
Tablonun hazırlanmasında MSUGT'da fonksiyon esası ve çeşit esası kullanılır, BOBİ FRS ve TMS'de ise sadece fonksiyon esas1 kullanılmaktadır

Tablo, 'Kâr veya Zarar ve Diğer Kapsamlı Gelir Tablosu' adıyla TMS' de iki bölümden oluşurken, BOBİ FRS ve MSUGT' da tek bölümdür. $\mathrm{Bu}$ bağlamda TMS/TFRS'ye göre raporlama yapan işletmelerde diğer kapsamlı gelir tablosu yer alırken BOBİ FRS'de ve MSUGT'da yer almamıştır. Diğer bir ifadeyle TMS'ye göre hazırlanan finansal durum tablosunda yer alan 'Kar Zararda Yeniden Sınıflandırılacak veya Sınıflandırılmayacak Diğer Kapsamlı Gelirler/Giderler', BOBİ FRS ve MSUGT'a göre hazırlanan finansal durum tablosunda (bilanço) ve özkaynak değişim tablosunda yer almayacaktır. Örneğin bir maddi duran varlığın değer artışı MSUGT ve BOBİ FRS'ye göre sadece özkaynaklar içerinde finansal durum tablosunda raporlanırken, TMS/TFRS'ye göre ayrıca diğer kapsamlı gelir de de raporlanabilecektir.

Tablolar arasında en büyük farklardan biri, MSUGT' da gelir ve giderler için yapılan olağan ve olağandışı ayrımının diğer iki tebliğde olmaması tüm gelir ve giderlerin işletme faaliyetleri içerisinde olağan sayılmasıdır.

Tablo-11: Ölçüm Esasları Açısından Karşılaştırma

\begin{tabular}{|l|l|l|}
\hline MSUGT & TMS/TFRS & BOBİ FRS \\
\hline -Tarihi Maliyet & - Tarihi Maliyet & -Tarihi Maliyet \\
& - Cari Değer & -Gerçeğe Uygun Sunum \\
& - Gerçeğe Uygun Değer & \\
& - Kullanım Değeri ve İtfa & \\
& Değeri & \\
& & \\
\hline
\end{tabular}

MSUGT'da ise finansal tablo kalemlerine ilişkin ölçümleme ve değerleme ölçütlerine detaylı bir şekilde yer verilmemiş tarihi maliyet esaslı bir ölçümlemenim yer aldığı görülmektedir.

TMS/TFRS - Finansal Raporlama için Kavramsal Çerçeve'de tarihi maliyet, cari değer, gerçeğe uygun değer, kullanım ve itfa değerleri ölçütlerine yer verilmiş ve detaylı olarak tanımlamaları yapılmıştır. BOBİ FRS' de ise gerçeğe uygun değer gibi başka bir ölçüm esası belirlenmediği sürece maliyet esaslı bir ölçüm öngörülmüştür. 
MSUGT, TMS/TFRS VE BOBİ FRS AÇISINDAN KAVRAMSAL ÇERÇEVE VE FINANSAL TABLOLARIN SUNULUŞU STANDARTLARININ DEĞERLENDİRILMESI

\section{SONUÇ}

BOBİ FRS uygulaması, 01/01/2018 tarihi itibariyle büyük ve orta boy işletmeler tanımına giren KAYİK'ler dışındaki bağımsız denetime tabi işletmeler için bireysel ve konsolide finansal tablolarının hazırlanmasında zorunlu hale getirilmiştir. Ulusal muhasebe sistemimizde MSUGT ve TMS/TFRS düzenlemeleri olmasına rağmen böyle bir ara düzenlemeye ihtiyaç duyulmasının sebepleri; MSUGT'da birçok değerleme hükümlerine yer verilmemiş veya isteğe bağlı bırakılmış olması, ayrıca var olan değerleme hükümleriyle ilgilide nasıl uygulanacağına yönelik açıklamaların yer almaması, vergisel kaygılardan ötürü reeskont ve karşılıklar gibi bir çok önemli muhasebe kaleminin ihtiyari bırakılması olmas1 gibi durumlardır. Çünkü bu durumlar finansal tabloların raporlama amaçlarından, gerçeğe ve ihtiyaca uygun sunum ve karşılaştırılabilirlik ilkelerinden uzaklaşmasına sebep olmaktadır. $\mathrm{Bu}$ işletmelerin tamamının Tam set TMS/TFRS uygulayamamasının sebepleri ise; standartların çok detaylı olması, özellikle orta boy işletmeler için ihtiyaçtan çok daha fazla hüküm içermesi ve anlaşılabilirlik noktasında sıkıntılar yaşanması, bazı ölçüm ve hesaplamaların bu işletmeler için karmaşık olmasıdır. Bahsi geçen bu sebeplerden ötürü KGK konuyla ilgili tüm paydaşların görüşünü almış ve MSUGT ile TMS/TFRS'leri birleştiren hem büyük hem de orta boy işletmelerin finansal raporlama açısından ihtiyaçlarını karşılayacak olan BOBİ FRS standartlarını yayımlamıştır. Bu standartlar genel olarak incelendiğinde yalın ve anlaşılabilir bir dille yazıldığı görülmektedir.

Hem MSUGT'a hem BOBİ FRS'ye hemde TMS/TFRS'lerin standart setleri incelendiğinde uygulamaların kalbini oluşturan ve finansal raporlamaya yön veren bölümlerin kavramsal bir çerçevenin çizildiği ve finansal tabloların sunuluşu hükümlerinin yer aldığı bölümler olduğu görülmektedir. Hem bu sebeplerden ötürü hem de BOBİ FRS ile ilgili literatür taraması yapıldığında bu bölümlerle ilgili MSUGT ve TMS/TFRS'lerdeki son değişiklikler ide içerecek şekilde detaylı bir karşılaştırma ve analizin olmamasından ötürü çalışmada bu bölümler her üç düzenleme açısından karşılaştırılmış ve sonuçlar tartışılmıştır.

Genel olarak bakıldığında BOBİ FRS uygulamaları orta boy işletmeler açısından MSUGT uygulamalarıyla benzeşirken büyük işletmeler açısından TMS/ TFRS uygulamalarına yakınsanmıştır. Bu durum bazı uygulamalarda kolaylık ve ihtiyaca uygunluk açısından olumlu olmakla birlikte bazı uygulamaklar da gerçeğe uygun sunum ilkesinden uzaklaşılmasına sebep olmuştur.

Örneğin BOBİ FRS'de küçük işletmeler için MSUGT'da olduğu gibi maliyet esaslı bir sunum öngörülmüşken büyük işletmeler için gerçeğe uygun değer ölçütü öngörülmüş ve ne şekilde kullanılacağı bölümler itibariyle açıklanmıştır. Yine ertelenmiş vergi varlığ̣ ve yükümlülüğüne 
ilişkin hesaplamalar büyük boy işletmeler için zaruri iken orta boy işletmeler için zaruri değildir. Bu durum özellikle orta boy işletmelerde değerleme ile ilgili ve ertelenmiş vergi geliri ve gideri ile ilgili karmaşıklığ ortadan kaldırmaktadır.

Öte yandan; duran varlıklarda TMS TFRS'lerde olan satış amaçlı duran varliklar ve durdurulan faaliyetler kavramlarının hem MSUGT hemde BOBI FRS'lerde olmaması raporlama yapılırken durdurulan ve sürdürülen ayrımı olmadan yapılmasına sebep olacaktır. Bu durum BOBİ FRS' nin gerçeğe uygun sunum iddiasına uymamaktadır. Ayrıca kapsamlı kar kavramının olmaması MSUGT ve BOBİ FRS'de olmaması maddi duran varlık değer artışları gibi kalemlerin diğer kapsamlı gelirde raporlanmamasına dolayısıyla yine gerçeğe uygun sunum noktasında eksikliğe sebep olacaktır.

Sonuç olarak kavramsal çerçeve ve finansal tablolarının sunuluşuna ilişkin MSUGT, TMS/ TFRS ve BOBİ FRS düzenlemelerin karşılaştırıldı̆̆ çalışmanın detaylı bir literatür ve tebliğ tarama sürecinden sonra hem 2020 yılından itibaren uygulanmaya başlayacak olan 'Finansal Raporların Sunuluşu'na İlişkin Kavramsal Çerçeve' ile ilgili önemli bilgiler vermesi hemde bahsi geçen tebliğlerin genel çerçeve ve mantığının anlaşılması sebebiyle bu alanda yeni çalışmalar yapacak olan akademisyenlere ve MSUGT uygulamalarından BOBİ FRS'ye geçiş sürecinde olan uygulayıcılara yol gösterici olacaktır.

\section{KAYNAKÇA}

Altıntaş, T. (2011). Uluslararası Muhasebe ve Türkiye'de Muhasebe Hukukui Sosyal Bilimler Dergisi, (1), 162-174.

Arar, M. (2018). BOBİ FRS Muhasebesi Her Konuda Örnek Uygulamalar Tek Düzen Hesap Planına Uygun Muhasebe Kayıtları TMS/TFRS ve VUK/MSUGT Karşılaştırmal1, $\quad$ http://www.bobiturk.com/wpcontent/uploads/bobi-frs-muhasebesi-1.pdf.

Başpınar, A. (2005). Türkiye'de ve Dünyada Denetim Standartlarının Oluşumuna Genel Bir Bakış, Maliye Dergisi, 148, 35-62.

Bekçi, İ., ve Özdemir, O. (2006). Muhasebe Standartlarının Oluşum Süreci ve Türkiye Finansal Raporlama Standartlarına Yönelik Muhasebe Meslek Mensuplarının Bakış Açıları Üzerine Bir Araştırma, Süleyman Demirel Üniversitesi İktisadi ve İdari Bilimler Fakültesi Dergisi, 11(2), 143-164.

Cavlak, H., Ataman, B., ve Gökçen, G., (2018). Muhasebe Sistemi Uygulama Genel Tebliği'ne (MSUGT'ye) Göre Hazırlanan Finansal Tabloların Büyük ve Orta Boy İşletmeler İçin Finansal Raporlama Standardı'na (BOBİ FRS'ye) Uyarlanması ve Rasyo Yöntemi İle 
Analizi, Finans Ekonomi ve Sosyal Araştırmalar Dergisi (FESA), 3(2), 458477.

Çalıyurt, K., T. ve Günay, S. G. (2017). "Prof. Dr. Fehmi Yıldız Anısına Muhasebe Finans Ve Denetimde Güncel Konular 2017" içinde "Ataman, B. (2017). TFRS Tam Set ile BOBİ FRS'larına Genel Bakış ve Değerlendirme, 9 - 23.", Trakya Üniversitesi Matbaası, Trakya Üniversitesi Bilimsel Araştırma Projesi 2017/174, Trakya Üniversitesi Yayın No:191, Edirne.

Çalıyurt, K.T. ve Günay, S. G. (2017). "Prof. Dr. Fehmi Yıldız Anısına Muhasebe Finans Ve Denetimde Güncel Konular 2017" içinde "Eskin, İ., (2017). BOBİ Finansal Raporlama Standartlarının Değerlendirilmesi, 34 42.”, Trakya Üniversitesi Matbaası, Trakya Üniversitesi Bilimsel Araştırma Projesi 2017/174, Trakya Üniversitesi Yayın No:191, Edirne.

Çalıyurt, K.T. ve Günay, S. G. (2017). "Prof. Dr. Fehmi Yıldız Anısına Muhasebe Finans Ve Denetimde Güncel Konular 2017" içinde "Gökçen, G., (2017). Üniversitelerimizde Okutulan Muhasebe Derslerinin İçeriklerinin, TFRS VE BOBİ FRS'lerdeki Gelişmeler Doğrultusunda Yeniden Ele Alınmas1, 24 - 33.”, Trakya Üniversitesi Matbaas1, Trakya Üniversitesi Bilimsel Araştırma Projesi 2017/174, Trakya Üniversitesi Yayın No:191, Edirne.

Doğan, A. (2018). Büyük ve Orta Boy İşletmeler için Finansal Raporlama Standardı ile VUK/MSUGT Karşılaştırması. Muhasebe ve Finansman Dergisi, (80), 115-132.

Ersan, Ö. Z. ve Çevikcan, F. (2010). Vergi Kanunlarıyla Getirilen Düzenlemelerin Muhasebe Uygulamasına Etkisi, Uluslararası Alanya İşletme Fakültesi Dergisi, 2(1), 113-128.

Gelir İdaresi Başkanlığı, 1 No’lu Muhasebe Sistemi Uygulama Genel Tebliği.

Gözlüklü, B. (2017). TMS/TFRS' lerdeki Değerleme İlkeleri Ve Vergi Sistemi İle Yakınsama Olanaklarının Araştırılması. Başkent Üniversitesi Sosyal Bilimler Enstitüsü İşletme Anabilim Dalı, Doktora Tezi.

Gücenme Gençoğlu, Ü. (2017). Temel Konularda BOBİ FRS ve TMS/TFRS Karş1laştırması. Journal of Accounting \& Finance, (76), 3-24.

Kamu Gözetimi Muhasebe ve Denetim Standartları Kurumu, Türkiye Muhasebe ve Finansal Raporlama Standartları.

Kamu Gözetimi Muhasebe ve Denetim Standartları Kurumu, Büyük ve Orta Boy İşletmeler İçin Finansal Raporlama Standardı.

Kayan, A. (2000). Verginin Tarihsel Gelişimi ve Sebep Olduğu Bazı Önemli Olaylar, Maliye Dergisi, 135, 80-87.

Muhasebe ve Vergi Uygulamaları Dergisi 
Kocamaz, H. (2012). Uluslararası Muhasebe Standartlarının Dünyada Ve Türkiye'de Oluşum ve Gelişim Süreci, Kahramanmaraş Sütçü İmam Üniversitesi İktisadi Ve İdari Bilimler Fakültesi Dergisi, 2(2), 105-120.

Nalan, A. ve Tenker, N. (2007). Finansal Tablolar ve Mali Analiz Teknikleri, Ankara, Gazi Kitapevi.

Öztürk, C. (2018). Yerel Finansal Raporlama Çerçevesi ve Büyük ve Orta Boy İşletmeler için Finansal Raporlama Standardı: Bir Literatür İncelemesi (2016-2017), Journal of Business Research Turk, 10/1, 763-781

Öztürk, E., ve Gökçen, G., (2017), Tam Maliyet Ve Normal Maliyet Yöntemlerinin Ufrs (Tfrs) Ve Bobi Frs'deki Düzenlemeler Çerçevesinde İncelenmesi. Finans Ekonomi ve Sosyal Araştırmalar Dergisi (FESA), 2(2), 105-114.

Öztürk, E., Gökçen, G., ve Güleç, Ö., F. (2018). BOBİ FRS ve TFRS’ni Finansal Raporlara Etkileri Açısından Karşılaştırılması, Finans Ekonomi ve Sosyal Araştırmalar Dergisi (FESA), 3(2), 437-457.

Şen, İ. K., \& Özbirecikli, M., (2018). BOBİ FRS'nin Muhasebe Uygulamalarına Getirdiği Değişiklikler: BOBİ FRS, TMS/TFRS ve Mevcut Muhasebe Sistemi Çerçevesinde Bir İnceleme.Muhasebe ve Vergi Uygulamaları Dergisi,(Özel Sayı), 462-484.

Tunçez, H., A. (2018). Büyük ve Orta Boy İşletmeler İçin Finansal Raporlama Standardı (BOBİ FRS) İle Türkiye Muhasebe Standartları (TMS) Arasındaki Temel Farklılıklar, Journal of International Social Research, 11(61).

Muhasebe ve Vergi Uygulamaları Dergisi 